Article

\title{
Rethinking 21st-Century Businesses: An Approach to Fourth Sector SMEs in Their Transition to a Sustainable Model Committed to SDGs
}

\author{
Ernestina Rubio-Mozos * $*$, Fernando Enrique García-Muiña $₫$ and Laura Fuentes-Moraleda $(\mathbb{D}$ \\ Faculty of Legal and Social Sciences, Rey Juan Carlos University, 28032 Madrid, Spain; \\ fernando.muina@urjc.es (F.E.G.-M); laura.fuentes@urjc.es (L.F.-M) \\ * Correspondence: ernestina.rubio@urjc.es; Tel.: +34-917024301
}

Received: 31 August 2019; Accepted: 21 September 2019; Published: 10 October 2019

check for updates

\begin{abstract}
With barely ten years remaining to reach the goals included in the United Nations 2030 Agenda (UN2030A), there is still no agreed-upon universal criterion regarding how businesses can move firmly forward to achieve them. A significant number of laudable initiatives have emerged and been consolidated internationally, highlighting the need to change the outdated mainstream economic model based on continuous growth-whose maximum exponent is the macroeconomic magnitude "Gross Domestic Product" (GDP)—to another sustainable model which considers the ecological "people and planet-centered" oriented limits, prioritizing individual wellbeing and social prosperity, in line with the UN2030A. Facing the prevalent resistance to change, some innovative small and medium-sized enterprises (SMEs) are consciously addressing the transition on their own, but not without difficulties. The purpose of this article was to fill the gap in the social sciences literature by conducting in-depth interviews with Fourth Sector (4S) entrepreneurs, business leaders from purpose-driven companies, and academics, in order to approach and look into their perspective about the role that 4S SMEs are being called to execute to advance toward 2030. The two main contributions of this article are (1) 4S SMEs identify an urgent need to modify the current economic model with metrics aligned with UN2030A and (2) it is essential to assemble and build an "Engagement Ecosystem" through a systemic thinking approach to allow 4S SMEs to make real contributions to the seventeen Sustainable Development Goals (SDGs).
\end{abstract}

Keywords: Sustainable Development Goals (SDGs); wellbeing economy; prosperity; transition; SMEs; Fourth Sector; purpose-driven companies; "for-benefit" companies; systemic change; "Engagement Ecosystem"

\section{Introduction}

Ten years after the Aspen Institute published "The emerging Fourth Sector" report [1], the "for-benefit" enterprises [2] were called upon to be the protagonists of a business revolution already underway, appropriately addressing the social and environmental challenges we face toward 2030, while at the same time providing prosperity to society and not just economic benefits to its partners and shareholders [3]. Although $4 \mathrm{~S}$ encompasses the public sector, private sector, and the third sector (non-profit organizations), this paper focuses only on the private sector, and more specifically, on SMEs.

$4 \mathrm{~S}$ organizations developed a business model strategically aligned with a purpose beyond pure economic profit (Figure 1), and this is the key, as they manage to create companies that are not only cost-effective but also sustainable, ethical and committed to generating a benefit for society and the planet [4]. 


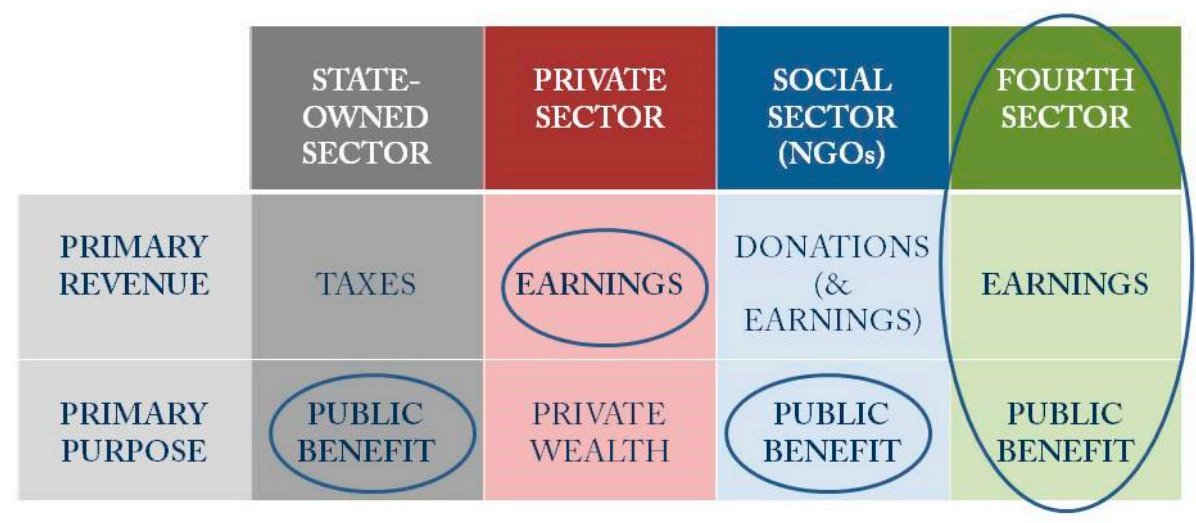

Figure 1. Fourth Sector organizations. Prepared by authors, adapted from "Fourth Sector Group" [1,5].

The $4 \mathrm{~S}$ is an upwardly mobile sector with strong potential to build an economic model that serves to improve the social and environmental environment [2]. However, the development of $4 \mathrm{~S}$ is tremendously complex, given that SMEs face numerous challenges and must overcome innumerable obstacles, given the current economic model whose main measurement parameter is GDP. As a result, most public policies implemented by States are aimed solely at fostering economic growth, without taking into account social and environmental externalities generated by business activity [6].

SMEs have an enormous specific weight in the economy of developed countries, as they account for ninety-nine percent of the businesses of OECD (Organization for Economic Co-operation and Development) countries and are responsible for seventy percent of jobs [7]. Therefore, SMEs are called upon to play a significant part in progressing towards SDGs; however, there is little literature on the role that SMEs should have to move towards a sustainable $4 \mathrm{~S}$, and thus advance the implementation of the UN2030A [8]. This research contributes to filling this existing gap in the matter.

Consequently, the contribution of this paper is the identification of how the 4S SMEs can advance to the UN2030A and thus collaborate in the necessary transition towards a more humane, inclusive, and sustainable economy. To achieve this objective, a qualitative method and a subsequent thematic analysis were carried out based on twelve in-depth interviews with experts. Selected entrepreneurs, business leaders, and academics were asked to reflect on three topics: (1) definitions and concepts that are under discussion, such as GDP (in effect), prosperity and well-being (advisable toward 2030) [9]; (2) the main barriers, issues and challenges that SMEs must overcome in their progress towards the Sustainable Development Goals and (3) knowing what contributions SMEs can make to converge with SDGs and how they can do it.

\section{From "Limits to Growth" to a "Sustainable Wellbeing Economy": The Role of SMEs in the Transition toward 2030}

Since the report "Limits to Growth" [10] was published in 1972, recent academic studies referring to degrowth [11] or alternatives to continuous growth proposing a development without growth [12] all underlined the urgent need to generate the debate to overcome the GDP demands of indefinite consumption and continuous annual growth and to bet for a "Sustainable Wellbeing Economy" [13]. The review of the literature indicates there were already methodological proposals that raised a discussion about GDP as a reference index in the last decade of the 20th-century. Although they did not raise its full replacement, they suggested the suitability of adding new parameters to it that included social and environmental metrics, calling it the Index of Sustainable Economic Welfare (ISEW) [14]. Since then, several proposals have been added to this initiative, including the Genuine Progress Indicator (GPI) [15], which considers the evolution of the ISEW and whose review and parameters have been extensively analyzed in the literature [16-21], the Social Progress Index (SPI) [22-24], the Happy Planet Index [25], launched and supported by the New Economics Foundation [26], and the Sustainable Wellbeing Index (SWI) [17], among others. In addition, there are national indices, such as 
the Living Standards Framework (LSF) in New Zealand [27,28], which represent a milestone and mark a country's leadership towards much-needed change by 2030 [28]. The European Union is developing inclusive indicators through its initiative "Beyond GDP initiative: Measuring progress, true wealth, and wellbeing" since 2007, and therefore admitting that GDP is not a measure of "prosperity and well-being" [29]. These are just some initiatives in the literature that we will support to initiate research focused on the role that $4 \mathrm{~S}$ SMEs must play to contribute to the SDGs.

However, they should not be limited to plausible initiatives. The climate crisis, the depletion of natural resources, and the sixth massive extinction of species are just some of the effects we are causing in the so-called Anthropocene epoch [30]. According to the Intergovernmental Panel on Climate Change (IPCC), the massive use of fossil fuels as the primary source of energy has been the driving force behind the economic growth we have seen for more than a hundred years, but also, the causes of climate change and the responses we must give to it are directly related to sustainable development [31]. Similarly, the data confirming the increase in inequality between people with higher purchasing power and the poorest continues to grow, something that should not surprise us because history shows us that it has been like this for decades [32]. As we have seen, since SMEs account for ninety-nine percent of the businesses in OECD countries, [7] is still no evidence of their contribution to UN2030A [8] and it is necessary to join efforts to facilitate their incorporation and overcome the challenges posed by the SDGs. There is little time, and there is much to do.

Therefore, there is an urgent need for a transition towards a new economic model whose measurement parameter expands the focus and includes social and environmental metrics aligned with the SDGs [17]. However, is it impossible for governments to move from a continuous economic growth model focused on a planet with finite resources to a sustainable one where metrics are the wellbeing of people and the planet?

No, it is not. There are already pioneering governments from highly-developed economies such as New Zealand and Scotland that have taken action and are leading this momentous movement. They begin to include specific social and environmental metrics that make it possible to understand better the real situation of citizens in their countries and how they can actively work to create prosperous societies, improving the wellbeing of their citizens and the ecosystems of their territories $[9,33]$. In the case of New Zealand, last May, for the first time, the government published its first national budget focused on wellbeing, introducing parameters relating to child poverty, inequality of indigenous communities, mental health, and climate change, among others [27]. A few months earlier (November 2018), together with the Governments of Scotland and Iceland and in the presence of Prof. Joseph Stiglitz and a prominent member of OECD, they created the Network of Wellbeing Economy Governments (WEGo) [34], which Costa Rica and Slovenia joined later. WeGo "seeks to promote the sharing of expertise and transferable policy practices among governments, who have a shared ambition of delivering wellbeing through their economic approach" $[29,35]$. There is, therefore, some degree of consensus on the need to implement appropriate indicators to address the global challenges of the 21st-century, such as climate change, the depletion of natural resources, health, social inequalities, poverty (to mention just a few) and ultimately, to measure societies' progress in terms of prosperity, sustainability and wellbeing, thus connecting with the spirit of the UN2030A.

It is not an isolated trend, but on the contrary: committed citizens join efforts to create networks for the advancement of sustainable practices [36]. It is a movement around the globe: different initiatives of various kinds are working with the ambition of rethinking the current economic model and adapting it to the SDGs in order to build a more inclusive, equitable society, and within planetary boundaries [37]. To mention a few (just scratching the surface), independent think-tanks such as the Center for the Understanding of Sustainable Prosperity (CUSP) [38], Rethinking Economics [39], New Economics Foundation [40], the International Institute for Sustainable Development [41], the Capital Institute [42], the Smart Economics for the Environment and Human Development (SEED) [43]; the academic world committed with sustainability such as the Cambridge Institute for Sustainable Leadership [44], the Stockholm Resilience Center [45], the University for International Cooperation [46] and its Centre 
for Applied Cultural Evolution [47] (launched together with the Capital Institute), the Post-Crash Economy from Pompeu Fabra University [48,49], the Institute for Global Prosperity [50], many of them publishing scientific articles and thus, contributing to create awareness of planetary boundaries and social challenges of the 21st-century; networks of organizations and individuals such as New Economy Network Australia [51], New Economy and Social Innovation (NESI Forum) [52], and last but not least, the international Wellbeing Economy Alliance (WEAll) [53]—connected with the WEGo network previously mentioned. Although still a minority, this shows a strong and trend.

Consequently, we would like to join this global awareness by contributing modestly with this article. The objective of this paper is to fill the gap in the social science literature and deepen the perspective of $4 \mathrm{~S}$ small and medium entrepreneurs and business leaders from five countries in Europe and Latin America to know their concerns about the current economic model and explore how they overcome the sustainability challenges toward 2030 and how growing Fourth Sector companies can definitely contribute to the advance of the implementation of the seventeen Sustainable Development Goals (SDGs) included in the UN2030A [54]. This is something that social sciences literature has still not addressed. Figure 2 shows a synthesis of this paper.

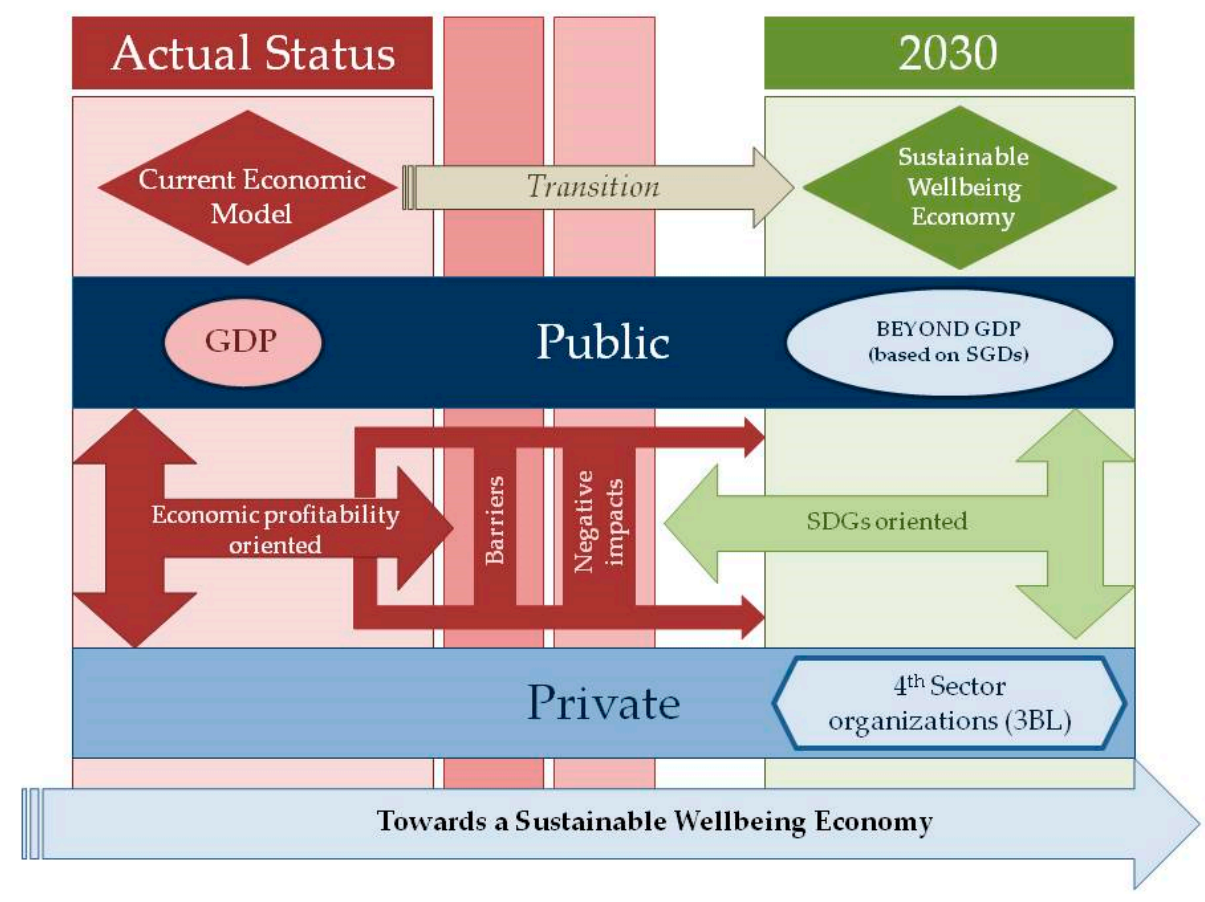

Figure 2. Diagram reflecting the synthesis of this article.

\section{Materials and Methods}

The methodology used in this study was qualitative, carried out by collecting data through twelve in-depth, semi-structured interviews, and carefully selecting the profiles to be interviewed, which we will analyze in detail below. This research was carried out transversally in five countries belonging to two geographical areas selected according to the objective criteria set out below: Europe and Latin America, specifically Argentina, Colombia, Costa Rica, Spain, and Portugal. The objective was first to identify how public policies can hinder or favor the development of sustainable businesses, and secondly, to describe the potential solutions that SMEs and specifically sustainable $4 \mathrm{~S}$ companies can provide to move towards SDGs. Before this, the research team introduced a reflection to the 4S SMEs about the validity and relevance of concepts and definitions about metrics of the current economic model (GDP) and others based on SDGs (prosperity and well-being).

For the development of the qualitative methodology, the state-of-the-art publications have been taken into account, in line with the stated objectives, thus establishing the correspondence between the 
problem to be investigated and the existing theory. With regard to the first research objective, the first questions posed to the interviewees were based on the article entitled "Modelling and measuring sustainable wellbeing in connection with the UN Sustainable Development Goals" [17], which deals with the analysis and revision of concepts in transition towards 2030 (GDP, prosperity and well-being). To address the second objective, we approached the difficulties, barriers, negative impacts, and issues that SMEs must overcome in their progress towards the SDGs. With this objective in mind, we will look at the negative needs and impacts they face from their perspective. Since we analyze public policies and topics and trends in the different countries, we designed the questions based on the report "Rewiring the Economy: Ten tasks, ten years" [55], published by the Cambridge Institute for Sustainability Leadership [56], which allows us to establish the correct framework to meet the second objective. Finally, to achieve the third objective, we rely on the ultimate report about the 4S [57], which was presented last May 2019 by the Ibero-American General Secretariat (SEGIB) [58], a supranational and multilateral organization that encompasses all Latin American countries plus Spain and Portugal, and is responsible for developing the $4 S$ project in these countries [59]. The geographic framework of the research (macro-regions of Europe and Latin America) is defined, therefore, by the $4 \mathrm{~S}$ report mentioned above. The approach carried out during the interviews allow us to go deeper into the results of the report, analyze them and assess whether, from the SMEs' point of view, their vision and demands coincide with those provided in the reference report (Figure 3).

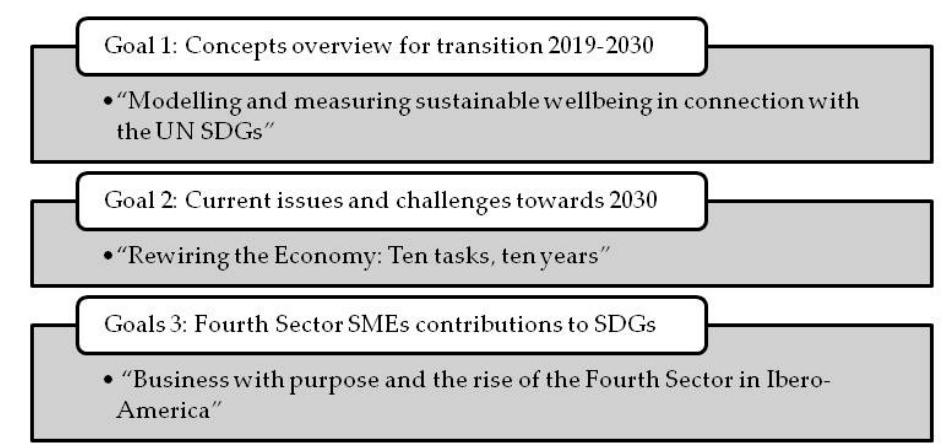

Figure 3. The correlation between research topics and their theoretical support references.

The investigation consisted of four phases: (1) Profile definition and interviewees selection; (2) Data collection; (3) Data analysis and (4) Results, as described below:

- Phase 1: Profile definition and interviewees selection: Given the lack of literature on 45 SMEs, this phase was relevant for qualifying interviewees. The first step was to define interviewees' profiles in order to comply with the research objectives. For this objective, four multi-criteria variables were defined: gender equality, age range, areas of knowledge and expertise, and macro-region representation (Figure 4), maintaining the balance in number within the first two criteria:
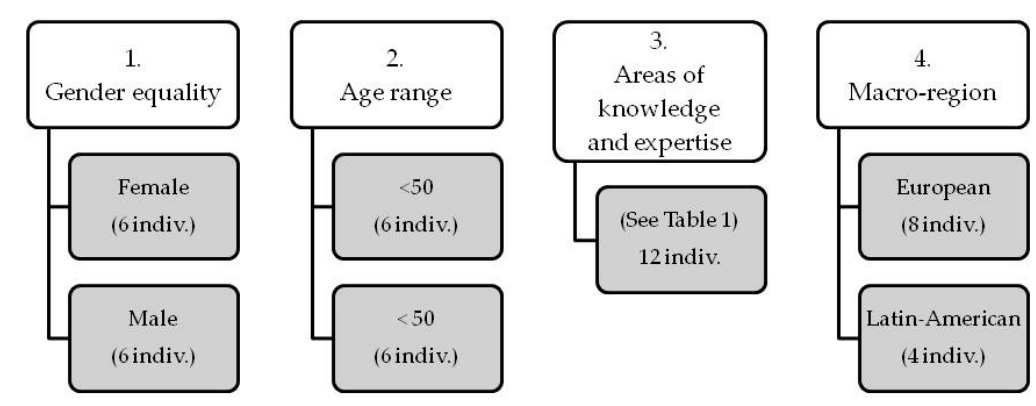

Figure 4. Diagram represents the four multi-criteria variables. 
The multi-criteria variables adopted and the combination between them allows the research team to proceed to the direct selection of the twelve people strictly chosen to meet the objectives of the research. Within the first two criteria, six people were selected in each of the variables, making a total of twelve individuals who meet one or the other sub-criterion. The third and fourth criteria-areas of knowledge, and macro-region representation-were given by the balance of the two previous ones. Since it was multi-sectorial research, it was sought that the interviewees jointly contribute a synthesis of several pivotal competencies, thus adding a trans-disciplinary and holistic vision to the research, as Table 1 shows. We emphasize that a requirement demanded in the selection of interviewees is their university or post-university education, and to have an in-depth knowledge of the challenges that sustainability and SDGs pose to SMEs, $4 \mathrm{~S}$ and the academic world. This careful selection also serves the purpose of avoiding information saturation.

Table 1. Interviewees' multi-criteria profiles.

\begin{tabular}{|c|c|c|c|c|}
\hline$\#$ & Gender & Age Range & Areas of Knowledge and Expertise & Macro-Region \\
\hline 1 & M & $<50$ & $\begin{array}{l}\text { Politic sciences, Sociology, and } 4 S \\
\text { entrepreneur }\end{array}$ & Europe \\
\hline 2 & $\mathrm{~F}$ & $>50$ & $\begin{array}{l}\text { Social innovation expert, consultant, } \\
\text { and } 4 \text { S entrepreneur }\end{array}$ & Europe \\
\hline 3 & $\mathrm{~F}$ & $<50$ & $\begin{array}{l}\text { Mathematics \& Exact Sciences, and } 4 S \\
\text { entrepreneur }\end{array}$ & Europe \\
\hline 4 & $\mathrm{~F}$ & $<50$ & $\begin{array}{l}\text { Social Anthropology, business leader, } \\
\text { and } 4 \text { S entrepreneur }\end{array}$ & Europe \\
\hline 5 & M & $<50$ & $\begin{array}{l}\text { Sustainable tourism expert, } \\
\text { University Professor, and researcher }\end{array}$ & LatAm \\
\hline 6 & $\mathrm{~F}$ & $<50$ & $\begin{array}{l}\text { New Economics network expert, and } \\
\text { business leader }\end{array}$ & Europe \\
\hline 7 & M & $>50$ & $\begin{array}{l}\text { Tourism expert, } 4 \text { S SMEs investor, } \\
\text { and business leader }\end{array}$ & Europe \\
\hline 8 & M & $>50$ & $\begin{array}{l}\text { Chemical engineering, Univ. Prof., } \\
\text { and researcher }\end{array}$ & LatAm \\
\hline 9 & M & $<50$ & $\begin{array}{l}\text { Community-based tourism expert, } \\
\text { Univ. Prof., } 4 \text { S entrepreneur }\end{array}$ & LatAm \\
\hline 10 & M & $>50$ & $\begin{array}{l}\text { Sustainable Tourism expert, } \\
\text { consultant, and } 4 \mathrm{~S} \text { entrepreneur }\end{array}$ & Europe \\
\hline 11 & $\mathrm{~F}$ & $>50$ & Degree in Law, and business leader & Europe \\
\hline 12 & $\mathrm{~F}$ & $>50$ & Psychology, and $4 S$ entrepreneur & LatAm \\
\hline
\end{tabular}

The selection of the interviewees was carried out directly through two channels: the business world and academia. The former was selected through business associations, whose partners are entrepreneurs who are aware and sensitive about social and environmental challenges posed by the SDGs and meet the parameters to be considered 4S. There was also a direct selection of senior managers and business leaders whose business models were inspired and led by a purpose. Academic interviewees linked to research centers and universities where multiple disciplines are taught with a focus on sustainability and sustainable and regenerative development were also selected. Table 1 shows detailed information relating to all variables.

- Phase 2: Data collection. The in-depth interview was the instrument of choice for the research. The interview consisted of twelve open-ended questions, structured into three blocks of questions: introductory, central, and concluding.

The interview process took place between February and July 2019. The research team conducted them, creating a climate of trust that allowed the interviewees to respond broadly and without a time limit, focusing on the topic, and specifying the question if necessary. The interviewees did not have previous access to the questionnaire so that the answers were spontaneous and could not be prepared 
beforehand. The average duration was one hour and twenty minutes, the shortest being fifty minutes and the longest being two hours and forty-five minutes. The in-depth interviews were carried out face-to-face, or alternately (in case of impossibility due to geographical distance), through computer communication tools that allowed recording with quality and in its totality. The responses were transcribed in Spanish, which is the original language of the interview, and translated subsequently into English. Table 2 shows the questions asked to interviewees, classified into the three themes in order to reach the objective.

Table 2. Interview questions classified into themes.

\begin{tabular}{|c|c|c|}
\hline $\begin{array}{l}\text { Theme 1: Reflections on } \\
\text { Concepts and Definitions: } \\
\text { Validity, Relevance, and } \\
\text { Perception from SMEs }\end{array}$ & $\begin{array}{l}\text { Theme 2: Reflections on the } \\
\text { Current Situation, and Issues to } \\
\text { Be Addressed for SMEs to Move } \\
\text { towards UN2030A }\end{array}$ & $\begin{array}{l}\text { Theme 3: Reflections on } \\
\text { Potential Solutions Given by } 4 S \\
\text { SMEs to Advance in the } \\
\text { Implementation of the SDGs }\end{array}$ \\
\hline \multirow{2}{*}{$\begin{array}{c}\text { GDP: Do you think GDP is the } \\
\text { valid macroeconomic magnitude } \\
\text { to advance towards } 2030 \\
\text { challenges? }\end{array}$} & \multirow{2}{*}{$\begin{array}{l}\text { Public policies: Which are the } \\
\text { main barriers and restrictions } \\
\text { SMEs are facing to move forward } \\
\text { to } 2030 \text { ? }\end{array}$} & $\begin{array}{c}\text { From an SME perspective, do you } \\
\text { consider SDGs as the solid } \\
\text { theoretical framework for a } \\
\text { wellbeing-centered economy? }\end{array}$ \\
\hline & & $\begin{array}{l}\text { Which should be the main pillars } \\
\text { of the new economic model valid } \\
\text { for } 2030 ?\end{array}$ \\
\hline \multirow{2}{*}{$\begin{array}{l}\text { Prosperity: Reflections on the } \\
\text { concept. In your opinion, is it } \\
\text { equivalent to the "standard of } \\
\text { living" concept? }\end{array}$} & \multirow{4}{*}{$\begin{array}{l}\text { Difficulties SMEs are facing: } \\
\text { Which are the negative impacts on } \\
\text { SMEs, and which the main issues } \\
\text { the need to overcome to move } \\
\text { towards } 2030 \text { ? } \\
\text { Main topics and trends in your } \\
\text { country or region }\end{array}$} & $\begin{array}{l}\text { Which solutions may bring a new } \\
\text { economy, sustainable and } \\
\text { wellbeing-centered in your } \\
\text { country or region? }\end{array}$ \\
\hline & & $\begin{array}{l}\text { Reflections on the role of the } \\
\text { Fourth Sector SMEs towards } 2030\end{array}$ \\
\hline \multirow{2}{*}{$\begin{array}{l}\text { Well-being: Reflections on the } \\
\text { concept. In your opinion, is it } \\
\text { equivalent to "quality of life"? }\end{array}$} & & $\begin{array}{c}\text { How to raise awareness in society } \\
\text { to involve most people in the } \\
\text { SDGs challenges? }\end{array}$ \\
\hline & & $\begin{array}{l}\text { Success stories that may be } \\
\text { extrapolated to other territories }\end{array}$ \\
\hline
\end{tabular}

- Phase 3: Data Analysis: The analysis of the data was carried out through thematic analysis. This type of analysis was the most appropriate for achieving our research objectives since it allowed the research team to identify, classify, and define thematic patterns in order to produce the final report. A thematic analysis leads to a better understanding and interpretation of the data. The analysis was carried out in six phases: data knowing; data coding; themes searching; reviewing; defining and naming; and report producing [60]. Although at the beginning, a qualitative analysis computer tool was used, most of the process was finally done manually given the complexity of the results obtained and the need to familiarize oneself with them in order to analyze them in-depth. This process led to the identification of the relevant variables in each of the dimensions.

- Phase 4: Results. Results were classified into three blocks in accordance with the themes: (1) a reflection on the three main concepts and definitions that will form part of the first block of questions; (2) identification of the main challenges toward 2030; and (3) potential solutions that $4 \mathrm{~S}$ SMEs may provide to the Sustainable Development Goals, finalizing with success stories carried out in different territories.

\section{Results}

The following results were carried out with SMEs entrepreneurs and business leaders from "purpose-driven" companies, as well as academics from five European and Latin American countries. The goals were to propose a reflection from the social sciences approach on the contribution that 
sustainable $4 \mathrm{~S}$ SMEs can and should work to contribute effectively to improve the living conditions of people and the planet, in line with UN2030A [54].

The results are presented according to the three themes presented above and, although summarized, the research team considered a non-synthetic description necessary given the scarce literature on the subject of 4 S SMEs.

4.1. Results on Concepts and Definitions: GDP, Prosperity, and Wellbeing. Validity, Relevance, and Perception from SMEs

Interviewees were asked to define current and potential metrics for the period 2019-2030. GDP being the current metric, they were asked if they considered GDP as a valid macroeconomic magnitude for 2030. It is worth mentioning that the interviewees were not experts in economics; however, they did have a real experience of the barriers that prevent the development of 4S SMEs: they faced public policies in which economic growth prevailed, and they knew how these negatively impacted their performance and contribution to the SDGs at the micro-level. Therefore, while there was a consensus among the interviewees as to the conception of the meaning of GDP, in terms of prosperity and wellbeing, it was perceived that emotional, cultural and social values had considerable influence.

Regarding this question, one hundred percent of the interviewees stated that the GDP was insufficient and not valid for the fulfillment of the SDGs. Similarly, all the interviewees suggested that while it is an economic magnitude that reflects a country's economic situation, it needs to incorporate social and environmental parameters that reflect the degree of compliance and progress in the SDGs' commitment: "GDP is a valid and rigorous but insufficient macroeconomic magnitude that was valid in the twentieth century. The GDP gives us the production-country data, but it cannot be related to welfare (...). The GDP must be accompanied by other future parameters that surely give us a social welfare dimension of a given area" (Interview 11).

In any case, all the interviewees agreed that it is necessary to incorporate social and environmental measurement parameters: "One of the indicators we like to introduce in companies is what we call "collective social wealth" (...), it is a win-win approach (...). We cannot say that GDP is not valid for 2030, what is clear is that it cannot be the main one (...), it is proper of a moment in which the economy automatically turned into welfare to the citizenship. This has been proven to be no longer the case. If we want the SDGs to be the guide for 2030, GDP cannot be the tool to measure progress, because (...) it is not people-centered (...) and the limits to growth are not in the equation" (Interview 2).

Twenty-five percent of the interviewees specifically mentioned other indices, such as the GPI [15,18-21,61,62]; the SPI [19,22-24], and the Gini Index [63], and also provided additional reflection on whether continuous growth is possible: "GDP is valid for obtaining information on a country at a given time only in economic terms, not including social or environmental values (...). In this sense, the proposal of the GPI and SPI are more effective if we want to achieve a society like the one that the SDGs effectively propose. There are more than ten years left until 2030, and there are many social elements such as education, access to health, culture, natural resources, etcetera that are not in the GDP (...). We can see how some countries still improving their GDP do not manage to attend nor solve some social problems that in other countries with GDPs not so high and that do not grow as much economically, in one way or another if they are better solved" (Interview 5).

Regarding the concept of prosperity, all the interviewees described that prosperity had a nuance of collectivity and community, something that is common to all. Prosperity is understood as a concept that encompasses three areas: the first one is a personal one, where progress cannot be conceived without it. The second one is the collective one, according to which it is not possible to achieve it if we produce damage or negative impacts along the way. The third one that considers it must also integrate values related to nature, the planet, and biodiversity: "Regardless of the definition given in the dictionary, for me prosperity is the improvement of living conditions and the environment, that is to say, I will be a prosperous person if I can improve my way of life with respect to the past. To be prosperous, for me, is to improve; therefore, it is an element that cannot be measured solely from the economic point of view" (Interview 7). The collective and 
community nuance was generalized among one hundred percent of the interviewees: "For me, prosperity is social welfare, not just individual welfare (...). It is the sum of individual well-being, and this well-being cannot be if there is no balance between the social, the economic, and the environmental" (Interview 11).

Interviewees who were entrepreneurs perceived that the term prosperity concerned them in particular as generators of wealth in a given territory: "I understand prosperity as something collective, a win-win, but not as a distribution between rich and poor, we are not talking about charity but as a mutual enrichment. I know there are a growing number of companies that already work like this" (Interview 2).

It was observed that there were answers with different nuances between the interviewees from Europe and Latin America. Both made a harsh analysis of what the concept of prosperity means in their respective societies. While in Latin America, prosperity is perceived as being intimately linked to the land, in Europe, the validity of an economic system is into question. The economy is unable to emerge again, even if the economic and financial crash began more than ten years ago: "The concept of prosperity in Latin America is undoubtedly very different from the prosperity of a European. That has to do with our culture, our vision that prosperity is based on land, on the social justice of territories, and that is not happening in much of our countries" (Interview 9, Latin American). "How can we talk about prosperity if in this "first world" society we have our young people who live worse than we do at their age? How can we talk about prosperity if work is increasingly precarious and there are severe possibilities that people of my generation will not receive a pension after having contributed for decades? (...) How can we talk about prosperity if during these years of crisis, the country's best professionals have emigrated, and it is very likely that they will not return?" (Interview 4, European).

Regarding the concept of wellbeing, the statement of SDG 3 read: "Ensure healthy lives and promote well-being for all at all ages". The targets and indicators of this goal are also basically related to health [64], thus assimilating this concept with that of wellbeing. The interviewees were asked if we can deduce that human wellbeing is linked only to physical aspects such as health. In addition to health, they were asked about other metrics that could be used to measure wellbeing. In short, the aim was to find out how, from their point of view, well-being could be measured and whether it is dissociated from economic capacity, as stated by Max-Neef [65-67]. All the interviewees perceived that wellbeing has an inherent emotional nuance that is closely related to sensations and that often has little or no relation to the individual's purchasing power. All the interviewees agreed on the difficulty of implementing measurement parameters, given the character of intangibility, subjectivity, and multiculturality. However, twenty-five percent of the interviewees expressed the need to establish methodology and parameters: "The measurement of well-being should incorporate factors related to sustainability, social inclusion and changes in social and family models" (Interview 11). "The measurement of well-being should be framed within each social and territorial reality (...) and always in harmony with the environment" (Interview 9).

\subsection{Results on Current Situation and Issues to Be Addressed for SMEs to Move toward UN2030A}

Within the second theme, in the first place, interviewees were asked about the barriers and restrictions SMEs are facing to move toward 2030, and what are the negative impacts on SMEs and the main issues they need to overcome to contribute to SDGs, mentioning main topics and trends in their countries or regions, if relevant.

Responses were significantly different by region. While Americans identified barriers at the micro-level, Europeans pointed to challenges at the macro-level. Latin American interviewees highlighted three main issues: One, the lack of support to SMEs; two, the lack of knowledge about sustainability and SDGs at the business level; and three, the need to create debates about the excessive use of natural resources: "SMEs in Costa Rica are more than ninety-five percent of the businesses (...), that is, they are practically the ones that move the entire economy of a small country like ours (...). However, we have not been able to assert or make people feel that SMEs are a very relevant factor in the production of wealth in my country" (Interview 5). "The barriers and negative impacts of public policies go far beyond the harm they can cause to companies and specifically to SMEs (...). This model of development of excessive consumption of natural 
resources must be part of a critical discussion at the global level (...) about how to construct a public policy from a development model that safeguards natural resources for the next generations" (Interview 9).

Sixty-seven percent of the interviewees agreed that often, some public policies seem to move in the opposite direction to the fulfillment of the SDGs, or that they do so much slower than necessary. It is also an urgent need to introduce educational models that form future leaders and business people who are aware of SDGs' social and environmental challenges: "I believe that we are moving towards a model that instead of seeking more equity, unfortunately, generates more and more differences" (Interview 7). "It is important to legislate on New Economics, to encourage them, because we are very slow, we are wasting time" (Interview 10). Seventy-five percent mentioned the importance of education and training: "The academic training given in many of the universities, etcetera is based on a vision of business management with models that obey a certain system, which is the capitalist system (...). Such is the education in which new leaders and managers are educated as they come to market" (Interview 7). How that education is received is often the cause of the failure of the new projects of SMEs: "At the educational level, I observe that we are not able to create higher studies that teach economic alternatives that are not the mainstream and extractive. Thus, SMEs that initiate sustainable and purposeful projects necessarily are born at the local level and with scarce possibilities of scaling. They are strongly dependent on political-economic conjunctures that have nothing to do with their performance, which makes them vulnerable" (Interview 12).

Fifty percent of the interviewees stated that some of the barriers and restrictions are determined by the dynamics of the capitalist economic model itself, which advances to "a radicalization of that model" (Interview 7). It fundamentally pursues the generation of economic profit, which "history has demonstrated that this profit does not always enjoy redistributive elements that are transversal" (Interview 7). Another barrier identified was politics, since "we have seen that it is dependant on the economy (...), since politicians are fundamentally valued for economic results achieved in a short period, and consequently governments are highly conditioned by economic pressures from capital and large corporations" (Interview 7). Moreover, public management is blocked by "short electoral cycles of four years (...), which in the end are reduced practically to two; therefore it is tremendously short term to implement changes in depth that require a long term" (Interview 1). In addition, "the territorial structure of the majority of the European States which, in matters such as the Environment, causes great difficulties of coordination between administrations in these matters where there are no frontiers" (Interview 1). Finally, there is also a cultural barrier in citizens, based on excessive consumerism, not reflective and uncritical: "There is a cultural barrier based on an economic model that (...) pushes us to consume and all this is incompatible with the UN2030A" (Interview 7).

Regarding the challenges that SMEs are facing in the current economic context, the interviewees argued that they focus on overcoming two main challenges: "the first one is technological barriers" (Interview 11), and the second one is the purely economic, short-term assessment in which projects are frequently assessed: "That is the predominant vision of the financial world. Therefore, it is a barrier to starting many projects with purpose; although it is true that in the last years ethical banking models, socially responsible investment funds, etcetera begin to appear, it is still a minority" (Interview 7).

Nevertheless, it seems that something is changing, as fifty percent of European interviewees say that "the European Union is beginning to discuss issues such as emission reductions" (Interview 10). However, they found that European policies should be aligned with national policies, and this is where "legislation should be much more interventionist in order to be able to advance in the commitments acquired with the SDGs and against Climate Crisis. I mean not only legislating fiscal incentives for companies, but also economic sanctions for those who do not comply" (Interview 10). "Fiscal barriers must be established to hinder the distribution of products that are being produced or delivered in an unsustainable manner" (Interview 8). 


\subsection{Results on Potential Solutions Given by $4 S$ SMEs to Advance in the Implementation of the SDGs}

Interviewees were asked if, from a SMEs perspective, they considered SDGs as a solid theoretical framework for a wellbeing-centered economy. All the interviewees confirmed that they were for changing the current economic model and moving towards a sustainable model, even further, to "procure the well-being of people and the survival of the planet" (Interview 11). They considered that it is a good roadmap that has been agreed upon internationally, and that therefore, it should help to shift the current model: "In general, they cover the big issues that we have to consider: biodiversity, climate change, water and energy and also social issues such as poverty, gender equity, sustainable cities, and so on. I do believe that it is a strategy, an agenda that truly puts us on a path of sustainability with a planetary future" (Interview 8). However, eighty-three percent of the interviewees immediately introduced nuances to this statement. They stated that it is necessary to apply a "more pragmatic approach to SDGs in order to avoid them becoming a voluntarist, minority, unsuccessful and therefore ephemeral or obsolete exercise" (Interview 7). With the SDGs approach, it will be possible to "bring them closer to companies—especially SMEs—and people" (Interview 6), but it will be necessary to "demystify them" (Interview 10), because they often found that "SDGs are considered often as a pose, a manifestation of intentions" (Interview 11).

However, the fundamental thing is to change "from environmental economics to ecological economics" (Interview 9). Likewise, they claimed to apply an integral approach: "the SDGs should not be seen separately, because health issues, poverty, education, the use of natural resources, climate change are problems that often go hand in hand" (Interview 5). Despite this, it is the "most powerful tool we have and offers an accessible and apolitical discourse" (Interview 1) so "it is necessary to start, and we will see later if it is necessary a version 2.0 or $3.0^{\prime \prime}$ (Interview 1 ).

In relation with the main pillars of a new economic model valid for 2030, one hundred percent of the interviewees agreed that an integrated approach must be taken, betting on a legislation that would allow companies to grow "with purpose", promoting the so-called New Economics, the application of the Triple Bottom Line [68], as well as supporting and promoting the still-emerging $4 \mathrm{~S}$ entrepreneurial. All these factors are fundamental factors to move towards a new sustainable economic model that would allow us to comply with the SDGs; however, there are weak points: "How do we put the SDGs into practice? From my point of view, New Economics such as the Blue Economy, the Circular Economy, the Economy of the Common Good, etcetera are strategies that are on the table, but more in theory than in practice" (Interview 11). All agreed to positively valuing the appearance of the New Economics, but that they are not exclusive, but complementary to each other: "I believe that there is no single model, it has to be a mix, a single approach would be insufficient given the challenges ahead. We are in constant evolution; it seems that there is no single theory validated as such". Twenty-five percent of Europeans mentioned the so-called "Doughnut Economy" [69] as a model, although "it is fundamental the collaboration of the Government and the financial sector to create incentives" (Interview 10).

Shifting the focus, seventeen percent of the interviewees indicated the importance of introducing the "company with purpose" model, because they stated that "establishing a purpose beyond economic benefit" (Interview 1), it is possible to "test, prototype, launch and add little by little" (Interview 2), created by companies that produce positive social and environmental impacts, that is, an economy that "is not charitable, but supportive" (Interview 12). Seventy-five percent of them stated that $4 S$ "is incredibly powerful" (Interview 9), but that "the consumer has the key to reward or condemn reprehensible behavior carried out by companies in the creation and provision of their products and services, but it is also necessary to be aware of reducing consumption" (Interview 9).

Concerning the potential solutions to a new sustainable and wellbeing-centered economic model, the interviewees first mentioned that "it would be able to face more efficiently the great challenges that we have before us as a society: the scarcity of resources, the climate crisis, and poverty" (Interview 3). Sixty-seven percent of the interviewees stated that this would contribute to improving people's lives, especially those of the most disadvantaged, allowing a redistribution of wealth "by improving the living conditions of (...) those who have fewer strengths and whose skills are limited" (Interview 5). Likewise, they specified that the first benefit would be the "reduction of negative impacts, contributing to generate greater awareness 
about conscious, responsible and critical consumption" (Interview 10), because "it would guarantee that each of the links in the value chain in the production of a good or service effectively receives a fair price and/or salary (...). The model would also ensure that we produce what is necessary without falling into overproduction and overexploitation of resources (...) while stimulating the acquisition of local products (...). It would also imply a better social climate, improving the quality of jobs and, consequently, reducing social risks such as exclusion, delinquency, migration, displacement from their territories (...) and finally, I believe that adding all the above, we would be assured for many more years a planet more alive, healthier that takes up what has always been a living space" (Interview 5).

However, the introduction of the New Economies by themselves would not be a solution in itself: "Can New Economics and the enterprises linked to these bring profound change? The answer is yes, but I do not think it is just a task for the businesses (...). Capitalism is omnipresent, and all these New Economics would develop within capitalism" (Interview 8). Thirty-three percent of those interviewed in Latin America mentioned hybrid models, inspired by Ostrom [70,71]: "In my opinion, none of the traditional economic models (socialist or capitalist) can provide a real solution to current problems (...). That is why I think that the emergence of hybrid models within capitalism (...) working at the local level is exciting" (Interview 9). Finally, seventeen percent of the interviewees stated that they knew that there are self-sufficient communities that, on a small scale, are already doing so but "lack the real political will to carry them out in a global manner" (Interview 12).

On the question about the role of SMEs toward 2030, seventy-five percent of the interviewees confirmed the importance of establishing strategic alliances and agreements. This would allow them to be stronger and more competitive in order to overcome the 2030 challenges: "Companies with purpose have to establish alliances in order to cease being SMEs, to achieve greater positive impacts" (Interview 1), establishing clear leadership that manages "brave companies that introduce parameters of the New Economics (...) to demonstrate that it is possible to advance toward another economic model. There is a lack of referents and a lack of communication" (Interview 4). In order to create these referents, it is necessary "to be profitable and efficient and to generate products and services that contribute value to society and consumers (...). We must have the vocation to improve the lives of all the people with whom we interact: stakeholders, not just shareholders" (Interview 7). At present, "the added value of a product or a service is related to marketing or distribution aspects, which are everything that makes a product attractive for purchase (...). However, we must add a social value, where the company and the consumer have the certainty that it will improve the conditions of society through the production and consumption of that good or service (...). The SMEs have achieved a competitive advantage traditionally sustained basically in the relation quality-price (...), and now we see more and more efforts to incorporate products with environmental, social, sustainable seals or certifications (Interview 5).

Communication is also a determining factor in establishing these referents and giving notoriety and relevance to projects with a purpose that are successful, since "if there is something that has a future, it is a company that really plans to contribute to UN2030A, which is commercialized by saying what its impact is in relation to these goals. Consumers need to be re-educated by focusing on critical and conscious consumption" (Interview 8) because SMEs "must be able to convey that every time someone buys that product from a responsible brand they are generating a value-chain benefit (...). Every time we buy, we have to ask ourselves what is behind all this, what productive process is there? Moreover, if although I do not like it, I buy it consciously, I must know that I am co-responsible (...) to a greater or lesser extent of what is behind it" (Interview 7). That achievement will come if companies manage to introduce "the SDGs in the agenda of the Management Committees, this should help the of the corporate strategic model transformation, marking a purpose that they begin to build now for the next ten years, and be fulfilling it (...). We know that it is not going to be easy, but we have to start (...) implementing indicators because we have to measure, we have to know what return there is" (Interview 2). 
Finally, the role the academic world must play was mentioned once again: they must create new studies with a different paradigm "coming out from the dynamics that have been implemented, establishing criteria oriented to the common good (...) and together with companies and governments they must participate in the development of the $4 S$ (...). Not only training new leaders but also in the dissemination of the research they are carrying out" (Interview 7).

On how to raise awareness in society to get most people involved in global SDGs challenges, fifty-eight percent referred to the need for disclosure of reference companies, pointing out that it is necessary "to give greater visibility to initiatives, entrepreneurs and projects (...). It is something that has to do with the media but also with the companies themselves, in how they communicate their achievements" (Interview 2). Moreover, they confirmed that the two areas efforts should focus on are information and education, but "both challenges are difficult to address. Information because citizens, unfortunately, have lost-without having renounced - one of their fundamental rights and that is the right to truthful and independent information (...), and this can only change through education. It is necessary to educate in the common good, in environmental sensitivity (...), to educate the opposite of what has done with us for decades and that is that we are not the owners of the planet" (Interview 7).

They pointed out that supranational entities such as the European Union "have a critical job to do in terms of calling for participation, because they must take sides as it is a global issue and this surpasses our States" (Interview 4). Consequently, it is fundamental "to direct efforts towards citizens as consumers (...) because if I as a consumer am aware that a certain product or service generates damage or harm, it is more likely that I will react to that brand (...). The perspective of a conscious consumer leads to much more responsible behavior" (Interview 7). New information and communication technologies are fundamental to the dissemination of efforts, and as proof of this, they pointed to the climate movement "Fridays for Future" led by sixteen-year-old Swedish activist Greta Thunberg [72] and supported by thousands of activists around the world, which "would be unthinkable to have achieved the same impact a few years ago" (Interview 9). The current technological revolution affects everything differently, "and the population is already participating in this transition spontaneously. Perhaps the most remarkable thing is that there is greater awareness of people and consumers towards administrators, politicians and entrepreneurs and not the other way around (...), and this is what attracts the most attention. That is why the SDGs are so opportune" (Interview 11). They pointed out the relevance of informing with closeness and spreading "about the SDGs in the educational centers, from the schools to the higher education (...) because the children and young people have a power of conviction within their families that sometimes the adults do not achieve. We can see it with the manifestations of Thunberg; she is a great example for all, not only for the youngest" (Interview 12). With their commitment, new generations remind us that since the "Declaration on the Responsibilities of the Present Generations Towards Future Generations" was signed at UNESCO over twenty years ago [73], very little progress has been made.

Ninety-two percent of interviewees agreed that "the educational context, from schools to universities, is fundamental. It is nice to have a day dedicated to Climate Change, but at this point, this is not enough, We have to put it on the educational agenda and of course in the university" (Interview 2). They emphasize that "science and the university play a key role in the evaluation of SDGs, for the generation of knowledge and its objectivity when creating valid measurement parameters, and this is a global challenge" (Interview 1). It is urgent that "the Academy begin to include programs to train professionals capable of explaining this message and of using innovation to transform the economy not into a socialist model, but to a new model within capitalism. If there is a future, it is that way" (Interview 8). 
The interviewees agreed on another fundamental component besides education: information, because "both have also been instruments that historically the oligarchies have tried to control and manipulate (...). We must feel the need to seek truthfulness, but also to feel responsible that change depends on each one of us (...), to stop blaming others and to take an active part in taking on responsibilities to change habits and attitudes" (Interview 7). That is where "ethics and commitment (...) come in, in public policy, in production, in the value chain, in consumers and citizens. It will be not possible to achieve the SDGs without this" (Interview 9). Similarly, it is necessary "to direct efforts in three areas: first, to be consistent with oneself (...) and to align our day-to-day actions with our values (...). Secondly, to pay special attention to the new generations because they are the ones who will take over from us and it will be necessary for them to have a different consciousness when they do so than the current generation (...). Finally, to value the strength we have as consumers, because what would happen if, for example, nobody drank Coca Cola until they did not use glass containers again, as they did years ago? ( ... )?" (Interview 5). Now, it is essential to involve the entire population. We must avoid giving SDGs a high perspective, but give them applications on a local level if we want to involve the majority of the population: "getting people to see them close (...), letting them know that SDGs are not a matter of scientists, governments or the United Nations, but a lot to do with our day-to-day lives" (Interview 5). Likewise, it is crucial to make citizens see that "environmentalism does not mean that it brings the end of capitalism (...) because this creates confusion and fear among an important part of the population (...). We have to know how to give people the idea that there is another way, and this will improve their welfare and will not affect their employments" (Interview 8).

Finally, interviewees were asked to mention success stories that can be of application to other territories, and there were several admirable examples on both continents. In Europe, at the Government level, it is very interesting to follow the Scottish experience within the WEAll network [74], and it is necessary "to start talking among all the interested parties to be able to replicate that model in other areas" (Interview 6). Forty-two percent of the interviewees mentioned Costa Rica, pointing out that they have known how to value their natural resources [75]. As a country, they have had the same strategic line for almost thirty years that "despite the changes of the government of different political signs, they have known how to continue in that line that favors a local and sustainable economy" (Interview 8). On questioning about references from companies "with a purpose" the interviewees mentioned several companies from different productive sectors that started the path by conviction some time ago: "Patagonia in the textile sector and Whole Foods in supermarkets" (Interview 7). This includes a considerable part of Costa Rica's tourism sector because "they know how to generate positive impacts in the communities, who develop a profitable business and also do it with a deep respect for the environment" (Interview 7). The creation of the "Sustainable Tourism Certification (CST) [76] was a milestone "because it makes an important difference in those companies that have it" (Interview 8). Similar engaging initiatives in the tourism sector are being carried out in Colombia within Community-based tourism, working together with the communities living within National Parks and "strengthening the entire value chain within the territory" (Interview 9). If this was possible to do the tourism sector, "it is not far from being possible to achieve it in other productive sectors such as fishing, livestock or agriculture" (Interview 9).

The following Table 3 provides a summary of the main results from the twelve interviews. 
Table 3. Summary of the results.

\begin{tabular}{|c|c|c|}
\hline Themes & Questions & Summary \\
\hline \multirow{3}{*}{ Theme 1: Concepts and definitions } & GDP & $\begin{array}{l}\text { - } \quad \text { Insufficient, not valid for compliance with the SDGs. } \\
\text { There is a need to incorporate sustainability parameters that reflect the degree of } \\
\text { compliance and progress towards the SDGs. } \\
\text { - Alternative indexes, such as GPI and SPI. }\end{array}$ \\
\hline & Prosperity & $\begin{array}{l}\text { - It is a concept with a nuance of collectivity and community, and it comprises the } \\
\text { personal, collective, and environmental spheres. }\end{array}$ \\
\hline & Well-being & $\begin{array}{l}\text { - It is a concept that goes beyond health. It has an active emotional and cultural } \\
\text { component, dissociated from the financial capacity of each individual. } \\
\text { - There is a need to establish measurement parameters. }\end{array}$ \\
\hline \multirow[t]{2}{*}{ Theme 2: Difficulties and main issues } & $\begin{array}{l}\text { Public policies: Barriers and } \\
\text { restrictions }\end{array}$ & $\begin{array}{l}\text { - } \quad \text { Short-term policies based on electoral cycles. } \\
\text { - } \quad \text { Lack of public policies to support SMEs, sometimes even contrary to the SDGs. } \\
\text { Need to develop new educational models that are aware of the social and } \\
\text { environmental challenges, in order to raise awareness for sustainable, critical, } \\
\text { reflective, and committed consumption. }\end{array}$ \\
\hline & $\begin{array}{l}\text { Difficulties, negative impacts, and } \\
\text { main issues SMEs are facing }\end{array}$ & $\begin{array}{l}\text { - } \quad \text { Only economic and short-term assessment of business projects. } \\
\text { - There is a need to align national policies with SDGs and establish tax incentives for } \\
\text { sustainable projects. } \\
\text { - Establish sanctions and barriers for unsustainable products. }\end{array}$ \\
\hline
\end{tabular}


Table 3. Cont

\begin{tabular}{|c|c|c|}
\hline Themes & Questions & Summary \\
\hline \multirow{21}{*}{ Theme 3: Potential solutions } & & The SDGs are an excellent opportunity to improve the current economic model. \\
\hline & $\begin{array}{l}\text { SDGs as a framework for a } \\
\text { wellbeing-centered economy }\end{array}$ & $\begin{array}{l}\text { - There is a need for a pragmatic approach, bringing them closer to companies } \\
\text { and people. }\end{array}$ \\
\hline & & Comprehensive, not individual, approach to the 17 SDGs. \\
\hline & & $\begin{array}{l}\text { - } \quad \text { Legislation that allows the sustainable } 4 S \text { to grow, with reliable and complementary } \\
\text { strategies (NEs, Triple Bottom Line, among others). }\end{array}$ \\
\hline & $\begin{array}{l}\text { Main pillars of the new sustainable, } \\
\text { economic model }\end{array}$ & $\begin{array}{l}\text { Sustainable, purpose-driven companies that create products and services with } \\
\text { positive social and environmental impacts. }\end{array}$ \\
\hline & & Conscious employees and consumers. \\
\hline & & Address global challenges, such as resource scarcity, climate crisis, and poverty. \\
\hline & $\begin{array}{l}\text { Solutions from a new sustainable, } \\
\text { well-being economy }\end{array}$ & $\begin{array}{l}\text { - Wealth redistribution, improving people's quality of life, and improving the } \\
\text { social climate. }\end{array}$ \\
\hline & & $\begin{array}{l}\text { - Reducing negative environmental impacts and raising awareness about responsible } \\
\text { and sustainable consumption. }\end{array}$ \\
\hline & & $\begin{array}{l}\text { - Create sustainable products and services with added social and } \\
\text { environmental value. }\end{array}$ \\
\hline & Role of sustainable, 4S SMEs & $\begin{array}{l}\text { - Establish strategic alliances and agreements to achieve a more significant } \\
\text { positive impact. }\end{array}$ \\
\hline & & Need for leadership to create sustainable $4 S$ business referents. \\
\hline & & $\begin{array}{l}\text { - Communication as a critical factor to give relevance to the sustainable } 4 \text { S SMEs and } \\
\text { create awareness in consumers. }\end{array}$ \\
\hline & \multirow{6}{*}{ Raise awareness in society } & Training, education, communication, and information. \\
\hline & & $\begin{array}{l}\text { The academic world must develop, publish, and disseminate studies based on the } \\
\text { new paradigm of sustainability to educate for the common good. }\end{array}$ \\
\hline & & $\begin{array}{l}\text { - Truthful and close communication that allows sustainable projects to be } \\
\text { made visible. }\end{array}$ \\
\hline & & New Technologies can help spread the message and participate in it. \\
\hline & & Disseminate SDGs at all educational levels. \\
\hline & & $\begin{array}{l}\text { - Information to be pro-active, change habits and skills and be able to involve most } \\
\text { citizens in the SDGs. }\end{array}$ \\
\hline & \multirow[t]{2}{*}{ Success stories } & Governments: Scotland, Costa Rica, New Zealand. \\
\hline & & Corporations: Patagonia, Whole Foods, the tourism sector in Costa Rica. \\
\hline
\end{tabular}




\section{Discussion}

SMEs play a fundamental role in the achievement of SDGs, especially in countries where they represent a high percentage of the national economy. However, it is necessary to make an enormous effort to get them globally to join the global challenge because the vast majority are not involved at all [77].

From the perspective of SMEs, the transition towards an economic model based on SDGs is a necessary and urgent demand, of enormous complexity and implications, given the addiction of our society to "economic growth" [13]. Moreover, it is precisely in this continuous growth where the sustainable 4S SMEs point that the core of the problem lies: if GDP continues to be the valid macro-economic magnitude, public policies will be dictated accordingly. Consequently, the contributions and efforts made by the 4S SMEs in social and environmental matters will not have value in their fair measure and, therefore, their development will not cease to be marginal, thus hindering progress towards the Sustainable Development Goals. The discussion on GDP has been on the table in expert circles for years, but the 4S SMEs interviewed also identified it as a very relevant barrier to moving towards the SDGs. However, it is worth mentioning that the OECD continues to speak of "economic growth" [7] and that $4 \mathrm{~S}$ was initially promoted, among others, by the World Economic Forum (WEF) [3], but perhaps it is an implicit recognition of the need to modulate the overexploitation of natural resources and improve social indicators.

In any case, we have, on the horizon of 2030, an exceptional opportunity for sustainable 4S SMEs to lead the way, creating and sharing bottom-up initiatives and leading a sincere and committed change, while creating awareness and critical spirit among consumers and citizens towards the companies that generate negative impacts on their value chain, who intuit in sustainability an opportunity for "greenwashing" [78].

First, governments must establish the appropriate legislative framework that favors the development of a sustainable $4 \mathrm{~S}$ and the transition from traditional models to models of sustainable strategic management. This must include legislation on fiscal, labor, and financial matters at supra-national, national, and even regional levels to create a regulatory base favorable to a sustainable $4 \mathrm{~S}$ without fear of including incentives and sanctions. It will also be necessary to address the establishment of an effective measurement system [79] and assessment methods of progress towards a Sustainable Wellbeing Economy and the SDGs [17]. Secondly, the academic community, which must propose an introduction, update and adaptation, at all educational levels, of transversal training aimed at studying the New Economies and new tools capable of generating wellbeing, creating awareness, compassion and sensitivity toward people, the planet and the rest of living beings, publish and disseminate research, as well as transfer knowledge. Last but not least, it is necessary to add an actor that has been repeatedly alluded to by the interviewees: civil society. Their individual and network participation is essential to create awareness, make sustainable, conscious, and responsible consumption in line with SDG 12, and exercise critical thinking towards mass media, both in the new generation and traditional.

This transition is, without a doubt, tremendously complex, as it should be the economic and financial power itself who bet on the change of model, something that does not seem possible, at least in the short term globally, although it is possible to do so at the national level. New Zealand has just begun down this path and this may allow some fair competition between countries. However, despite these almost isolated initiatives, and despite the fact that prominent international leaders and experts, such as Stiglitz, have been advocating for decades to modify GDP [79], in reality, there have been no substantial advances in supranational institutions to make this change effective because the measurement parameters would influence the ranking of countries with higher political power. The current GDP system was adopted in the first half of the 20th-century and, according to Fioramonti, the GDP "is not just a number, but the ultimate objective of policy and a global benchmark for success" [80]. The GDP measurement, therefore, establishes a logic and rankings of global power (G7, G20) that would be altered in the case of introduction of other metrics and parameters, giving entry to countries that, with the current GDP measurement, have less economic weight but better quality of life and welfare of their citizens, according to indices such as the World Happiness Report [9,81]. Despite this, the proposals and demands do not cease: the most recent one was made by the WEAll network to the 
G7 leaders gathered at the Summit at the end of August 2019 in the French city of Biarritz under the title "7 ideas for G7" [82,83].

\section{Conclusions}

Addressing this research around the Sustainable Development Goals, 4S and SMEs were necessary, given their specific weight in the economy of the most developed countries and the need to advance towards 2030, something that, from the perspective of social sciences, has scarcely been addressed so far.

It is essential for SMEs to begin the transition towards a sustainable $4 S$, introducing "purpose" $[57,84,85]$ into their strategic management line, demonstrating economic, social and environmental results through measurement, transparency and, where appropriate, certification. SMEs need to create business leaders and references that serve as examples and lead the way and form networks in which they join efforts and resources can create prosperity and wellbeing, and also to be more effective in their message.

However, 4S SMEs cannot do this alone. Although they account for more than ninety-nine percent of businesses in many countries with capitalist economies, their leading role is still a minority. Hence a systemic thinking approach is needed to create a multi-stakeholder $[86,87]$ ecosystem that we propose to call "4S SMEs Engagement Ecosystem", in which the Government, the academic world and civil society organizations would become part, each with a role and a task to perform. This concept is inspired by the "business ecosystem" used in the report "Enhancing the contributions of SMEs in a global and digitalized economy" by the Organization for Economic Co-operation and Development (OECD) [7], in the "Supportive Ecosystem" of the Fourth Sector Group [86], in the "cluster" mentioned in the paper "Sustainable business models, venture typologies, and entrepreneurial ecosystems: A social network perspective" [87], and in the "Hub" concept by WEAll [88], but adding and introducing the concept of engagement, given its relevance to ecosystem change and for the reasons set out below.

The two main conclusions of this article are as follows: (1) 4S SMEs need an urgent economic model change, starting by the introduction of GDP environmental and social metrics aligned with the SDGs [16]; (2) it is essential to take a systemic thinking approach between the private sector and the other key actors of society (Government, academic community and civil society) to assemble and build a "4S SMEs Engagement Ecosystem" in the next three-to-five years. These will allow 4 S SMEs to overcome the sustainability challenges posed by the SDGs and contribute effectively and measurably to a "Sustainable Well-being Economy" (Figure 5).

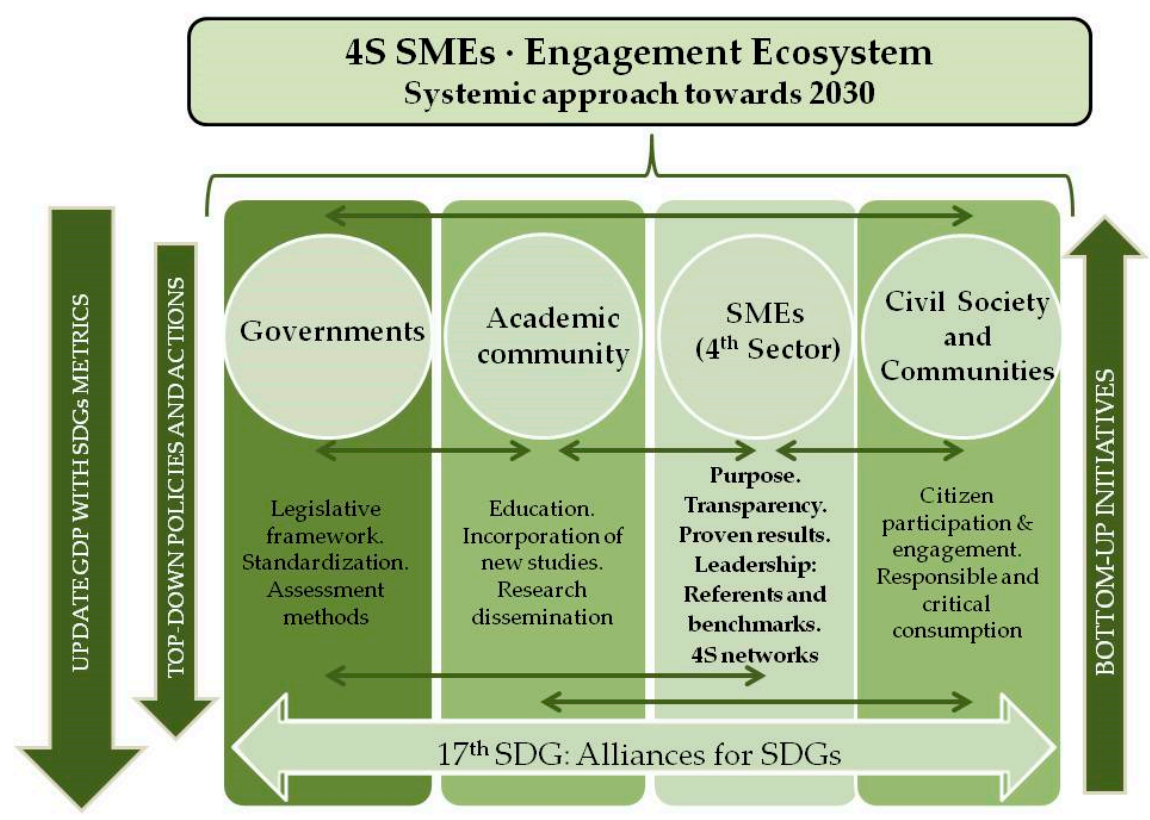

Figure 5. The conclusions of this article and the proposed "Engagement Ecosystem". 


\section{Limitations and Future Lines of Research}

The qualitative nature of this paper was based on an in-depth evaluation of experts' opinions; consequently, this technique has certain restrictions. Likewise, although the sample size was defined to avoid information saturation, it was circumscribed to two macro-regions (Europe and Latin America) that coincide with the defined theoretical framework. Likewise, quantitative studies that could have complemented the qualitative results could not be provided given the scarce development of the sector in the geographical areas analyzed.

Given the limited bibliography focused on the research topic of this article (4S, SMEs, and SDGs), it seems necessary that future research areas complement the results and conclusions of this study. The generation of the literature on this subject and its dissemination may help purpose-driven companies-especially SMEs- to be recognized and valued by society, not only for their economic outcome, but for the real value they are bringing to their communities.

In the same way, it would be desirable to conduct global research in the five continents, both qualitative and quantitative, that would allow a broader perspective of the situation. This potential global study would undoubtedly broaden the results and conclusions of this paper, since Oceania was not included, which is precisely where the first steps toward a more caring, inclusive, and sustainable economy are being taken. The same shall apply with macro-regions with strong economic growth, such as Asia and Africa.

Further research on successful models that have been carried out at the local level and small scale, both territorially and sectorally (such as community-based tourism), may be of great interest given their potential replicability. Additionally, as in the above example, bringing a gender focus and an eco-feminist perspective could make a very positive contribution to the limited literature on the subject.

As a consequence and in line with the conclusions obtained, we suggest two additional lines of research: First, the development of a theoretical, sectorial design of SDGs implementation methodology in 4 S SMEs, with a value chain perspective and multi-stakeholder approach. Secondly, the design of strategies to assemble and build a "4S SMEs Engagement Ecosystem" from a systemic thinking approach, applied to a case study to verify its validity and possible transferability and applicability.

Author Contributions: Conceptualization, E.R.-M.; Data curation, E.R.-M.; Formal analysis, E.R.-M.; Investigation, E.R.-M.; Methodology, E.R.-M.; Supervision, F.E.G.-M. and L.F.-M.; Validation, F.E.G.-M. and L.F.-M.; Writing—original draft, E.R.-M.; Writing—review \& editing, F.E.G.-M. and L.F.-M.

Funding: This research received no external funding.

Acknowledgments: We acknowledge the participants in this research project for their time dedicated to the interview. Their participation and generosity are highly valued.

Conflicts of Interest: The authors declare no conflict of interest.

\section{References}

1. Fourth Sector Network. The Emerging Fourth Sector About Fourth Sector Network; Fourth Sector Network: Washington, DC, USA, 2009.

2. Sabeti, H. The For-Benefit Enterprise. Harv. Bus. Rev. 2011, 89, 98-104.

3. United Nations Development Programme. The Fourth Sector: Can Business Unusual Deliver on the SDGs? UNDP. Available online: https:/www.undp.org/content/undp/en/home/blog/2018/the-fourth-sector--canbusiness-unusual-deliver-on-the-sdgs.html (accessed on 24 May 2019).

4. Jímenez Escobar, J.; Morales Gutiérrez, A.C. Social economy and the fourth sector, base and protagonist of social innovation. CIRIEC-España Rev. Econ. Pública Soc. Coop. 2011, 73, 33-60.

5. What Are For-Benefit Organizations? Available online: https://www.fourthsector.org/for-benefit-enterprise (accessed on 30 September 2019).

6. Max-Neef, M. The good is the bad that we don't do. Economic crimes against humanity: A proposal. Ecol. Econ. 2014, 104, 152-154. [CrossRef] 
7. OECD; Council, O.; Level, M. OECD Enhancing the contributions of SMEs in a global and digitalised economy. In Proceedings of the Meeting of the OECD Councilat Ministerial Level, Paris, France, 7-8 June 2017; pp. 7-8.

8. Pomare, C. A multiple framework approach to sustainable development goals (SDGs) and entrepreneurship. Contemp. Issues Entrep. Res. 2018, 8, 11-31.

9. Coscieme, L.; Sutton, P.; Mortensen, L.F.; Kubiszewski, I.; Costanza, R.; Trebeck, K.; Pulselli, F.M.; Giannetti, B.F.; Fioramonti, L. Overcoming the Myths of Mainstream Economics to Enable a New Wellbeing Economy. Sustainability 2019, 11, 4374. [CrossRef]

10. Meadows, D.H.; Meadows, D.L.; Randers, J.; Behrens, W.W., III. The limits to growth. A report for The Club of Rome's Projecton the predicament of Mankind; Universe Books: New York, NY, USA, 1972; ISBN 0-87663-165-0.

11. Büchs, M.; Koch, M. Challenges for the degrowth transition: The debate about wellbeing. Futures 2019, 105, 155-165.

12. Tukker, A. Prosperity Without Growth: The Transition to a Sustainable Economy by Tim Jackson. J. Ind. Ecol. 2010, 14, 178-179. [CrossRef]

13. Costanza, R.; Caiglia, E.; Fioramonti, L.; Kubiszewski, I.; Lewis, H.; Lovins, H.; McGlade, J.; Mortensen Lars, F.; Philipsen, D.; Pickett, K.; et al. Toward a Sustainable Wellbeing Economy Club of Rome. Solutions 2018, 9, 2.

14. Stockhammer, E.; Hochreiter, H.; Obermayr, B.; Steiner, K. The Index of Sustainable Economic Welfare (ISEW) as an alternative to GDP in measuring economic welfare. The results of the Austrian ISEW calculation. Ecol. Econ. 1996, 21, 19-34. [CrossRef]

15. Lawn, P.A. A theoretical foundation to support the Index of Sustainable Economic Welfare (ISEW), Genuine Progress Indicator (GPI), and other related indexes. Ecol. Econ. 2003, 44, 105-118. [CrossRef]

16. Max-Neef, M. The world on a collision course and the need for a new economy. Ambio 2010, 39, $200-210$. [CrossRef] [PubMed]

17. Costanza, R.; Daly, L.; Fioramonti, L.; Giovannini, E.; Kubiszewski, I.; Mortensen, L.F.; Pickett, K.E.; Ragnarsdottir, K.V.; De Vogli, R.; Wilkinson, R. Modelling and measuring sustainable wellbeing in connection with the UN Sustainable Development Goals. Ecol. Econ. 2016, 130, 350-355. [CrossRef]

18. Lawn, P.; Clarke, M. The end of economic growth? A contracting threshold hypothesis. Ecol. Econ. 2010, 69, 2213-2223. [CrossRef]

19. Howarth, R.B.; Kennedy, K. Economic growth, inequality, and well-being. Ecol. Econ. 2016, 121, $231-236$. [CrossRef]

20. Kubiszewski, I.; Costanza, R.; Franco, C.; Lawn, P.; Talberth, J.; Jackson, T.; Aylmer, C. Beyond GDP: Measuring and achieving global genuine progress. Ecol. Econ. 2013, 93, 57-68. [CrossRef]

21. Berik, G.; International Labour Organization. Toward More Inclusive Measures of Economic Well-Being: Debates and Practices; International Labour Organization: Geneva, Switzerland, 2018.

22. Porter, M.E.; Stern, S. SOCIAL PROGRESS INDEX 2014-Executive Summary. Available online: socialprogressimperative.org (accessed on 12 August 2019).

23. Fehder, B.Y.D.; Stern, S. The Social Progress Imperative. Soc. Prog. Index 2013 2013, 2, 11-38.

24. 2019 Social Progress Index. Available online: https://www.socialprogress.org/ (accessed on 30 September 2019).

25. New Economics Foundation Happy Planet Index. Available online: http://happyplanetindex.org/ (accessed on 24 June 2019).

26. New Economics Foundation The Happy Planet Index|New Economics Foundation. Available online: https://neweconomics.org/2006/07/happy-planet-index (accessed on 24 July 2019).

27. New Zealand Government. The Treasury Measuring Wellbeing: The LSF Dashboard. Available online: https://treasury.govt.nz/information-and-services/nz-economy/living-standards/our-living-standardsframework/measuring-wellbeing-lsf-dashboard (accessed on 10 August 2019).

28. Graham-McLay, C. New Zealand's Next Liberal Milestone: A Budget Guided by 'Well-Being'-The New York Times. Available online: https://www.nytimes.com/2019/05/22/world/asia/new-zealand-wellbeingbudget.html (accessed on 2 August 2019).

29. European Commission Beyond GDP: Measuring Progress, True Wealth, and Well-Being. Available online: https://ec.europa.eu/environment/beyond_gdp/index_en.html (accessed on 1 August 2019).

30. Smithsonian.com What Is the Anthropocene and Are We in It?|Science|Smithsonian. Available online: https://www.smithsonianmag.com/science-nature/what-is-the-anthropocene-and-are-we-in-it-164801414/ (accessed on 23 August 2019). 
31. Summary for Policymakers. Available online: https://www.ipcc.ch/site/assets/uploads/sites/2/2019/05/SR15_ SPM_version_report_LR.pdf (accessed on 8 September 2019).

32. Wealth Inequality Keeps Widening. But It's Nothing New|World Economic Forum. Available online: https: //www.weforum.org/agenda/2017/12/wealth-inequality-has-been-widening-for-millennia/ (accessed on 10 June 2019).

33. Giannetti, B.F.; Agostinho, F.; Almeida, C.M.V.B.; Huisingh, D. A review of limitations of GDP and alternative indices to monitor human wellbeing and to manage eco-system functionality. J. Clean. Prod. 2015, 87, 11-25. [CrossRef]

34. Wellbeing Economy Governments WEGo-Background. Available online: http://wellbeingeconomygovs. org/background/ (accessed on 10 August 2019).

35. Wellbeing Economy Governments WEGo-Wellbeing Economy Governments. Available online: http: //wellbeingeconomygovs.org/ (accessed on 10 August 2019).

36. SustainAbility Trends 2019. Available online: https://trends.sustainability.com/citizen-power/ (accessed on 19 July 2019).

37. Trebeck, K. WEAll Citizens|A New Economy for All-Katherine Trebeck Writes for UN Association. Available online: https://wellbeing-economy-alliance-trust.hivebrite.com/news/202657 (accessed on 26 July 2019).

38. CUSP Centre for the Understanding of Sustainable Prosperity. Available online: https://www.cusp.ac.uk/ (accessed on 26 August 2019).

39. Rethinking Economics. Available online: http://www.rethinkeconomics.org/ (accessed on 26 July 2019).

40. New Economics Foundation Together We Can Change the Rules to Make the Eeconomy Work for Everyone|New Economics Foundation. Available online: https://neweconomics.org/ (accessed on 26 June 2019).

41. IISD|International Institute for Sustainable Development. Available online: https://www.iisd.org/ (accessed on 10 June 2019).

42. Capital Institute-Co-creating the Regenerative Economy. Understand. Inspire. Available online: https: //capitalinstitute.org/ (accessed on 6 June 2019).

43. Smart Economics for the Environment and Human Development (SEED). Available online: http://www. smart-development.org/about (accessed on 8 August 2019).

44. Prosperity in Africa. Available online: https://www.ascleiden.nl/content/webdossiers/prosperity-africa (accessed on 16 August 2019).

45. Stockholm Resilience Centre-Stockholm University. Available online: https://www.stockholmresilience.org/ research/our-research-focus.html (accessed on 26 July 2019).

46. UCI University for International Cooperation, UCI. Available online: https://www.uci.ac.cr/certificateregenerative-entrepreneurship/ (accessed on 15 August 2019).

47. Center for Applied Cultural Evolution Center for Applied Cultural Evolution. Available online: https: //culturalevolutioncenter.org/ (accessed on 1 August 2019).

48. Post Crash Economy-Pompeu Fabra University. Available online: https://postcrashbarcelona.wordpress. com/ (accessed on 26 August 2019).

49. Rethinking Economics-Post-Crash UPF. Available online: http://www.rethinkeconomics.org/re-group/postcrash-upf/ (accessed on 15 July 2019).

50. UCL Institute for Global Prosperity-UCL-London's Global University. Available online: https://www.ucl.ac. uk/bartlett/igp/ (accessed on 18 June 2019).

51. New Economy Network Australia. Available online: https://www.neweconomy.org.au/ (accessed on 28 July 2019).

52. NESI Forum-New Economy and Social Innovation. Available online: https://nesi.es/ (accessed on 20 August 2019).

53. WEAll Wellbeing Economy Alliance-Building a Movement for Economic System Change. Available online: https://wellbeingeconomy.org/page/10 (accessed on 1 October 2019).

54. UN General Assembly. Transforming Our World: The 2030 Agenda for Sustainable Development; UN General Assembly: New York, NY, USA, 2015.

55. Reynolds, J. Rewiring the Economy: Ten Tasks, Ten Years; Cambridge Institute for Sustainability Leadership: Cambridge, UK, 2016.

56. University of Cambridge Cambridge Institute for Sustainability Leadership. Available online: https: //www.cisl.cam.ac.uk/ (accessed on 1 August 2019).

57. Secretaría General Iberoamericana (SEGIB). Business with Purpose and the Rise of the Fourth Sector in Ibero-America; Secretaría General Iberoamericana (SEGIB): Madrid, Spain, 2019. 
58. SEGIB|Secretaría General Iberoamericana. Available online: https://www.segib.org/en/ (accessed on 26 May 2019).

59. The Fourth Sector in Ibero-America-Fostering Social \& Sustainable Economy. Available online: https: //www.elcuartosector.net/en/ (accessed on 26 June 2019).

60. Braun, V.; Clarke, V.; Hayfield, N.; Terry, G. Thematic Analysis. J. Transform. Educ. 2018, 16, 175.

61. Kubiszewski, I.; Costanza, R.; Gorko, N.E.; Weisdorf, M.A.; Carnes, A.W.; Collins, C.E.; Franco, C.; Gehres, L.R.; Knobloch, J.M.; Matson, G.E.; et al. Estimates of the Genuine Progress Indicator (GPI) for Oregon from 1960-2010 and recommendations for a comprehensive shareholder's report. Ecol. Econ. 2015, 119, 1-7. [CrossRef]

62. Fox, M.J.V.; Erickson, J.D. Genuine Economic Progress in the United States: A Fifty State Study and Comparative Assessment. Ecol. Econ. 2018, 147, 29-35. [CrossRef]

63. Fuller, M.; Dwivedi, P. Assessing Changes in Inequality for Millennium Development Goals among Countries: Lessons for the Sustainable Development Goals. Soc. Sci. 2019, 8, 207. [CrossRef]

64. Goal 3: Sustainable Development Knowledge Platform. Available online: https://sustainabledevelopment. un.org/sdg3 (accessed on 23 August 2019).

65. Max-Neef, M. Economic growth and quality of life: A threshold hypothesis. Ecol. Econ. 1995, 15, 115-118. [CrossRef]

66. Cruz, I.; Stahel, A.; Max-Neef, M. Towards a systemic development approach: Building on the Human-Scale Development paradigm. Ecol. Econ. 2009, 68, 2021-2030. [CrossRef]

67. Max-Neef, M.; Elizalde, A.; Hopenhayn, M.; Herrera, F.; Zemelman, H.; Jatoba, J.; Weinstein, L. Desarrollo a Escala Humana una opcion para el futuro (versión de Cepaur Fundación Dag Hammarskjold). Dev. Dialogue Numer. Espec. 1986, 62.

68. Elkington, J. Enter the Triple Bottom Line (Chapter 1). In The Triple Bottom LIne. Does it All Add up? Assessing the Sustainability of Business and CSR; Henriques, A., Richardson, J., Eds.; Taylor \& Francis: New York, NY, USA, 2004; pp. 24-51. ISBN 9781844070152.

69. Raworth, K.; Doughnut. Kate Raworth. Available online: https://www.kateraworth.com/doughnut/ (accessed on 14 August 2019).

70. Ostrom, E. Institutions and the environment. Econ. Affairs 2008, 28, 24-31. [CrossRef]

71. McKean, M.; Ostrom, E. Common property regimes in the forest: Just a relic from the past? Unasylva 1995, 180, 3-15.

72. FridaysForFuture. Available online: https://www.fridaysforfuture.org/ (accessed on 10 August 2019).

73. UNESCO. Declaration on the Responsibilities of the Present Generations Towards Future Generations. In Proceedings of the Records of the 29th Session of the General Conference, Paris, France, 18-28 August 1997; United Nations Educational, Scientific and Cultural Organization: Paris, France, 1998; Volume 1, pp. 69-71.

74. WEAll Scotland-Wellbeing Economy Alliance. Available online: https://wellbeingeconomy.org/scotland (accessed on 21 August 2019).

75. Farley, J.; Costanza, R. Payments for ecosystem services: From local to global. Ecol. Econ. 2010, 69, $2060-2068$. [CrossRef]

76. Certificación Para la Sostenibilidad Turística-CST Costa Rica. Available online: https://www.turismosostenible.co.cr/ (accessed on 9 August 2019).

77. Frey, M.; Sabbatino, A. The Role of the Private Sector in Global Sustainable Development: The UN 2030 Agenda. In Corporate Responsibility and Digital Communities; Springer: Berlin, Germany, 2018; pp. 187-204.

78. The Guardian the Troubling Evolution of Corporate Greenwashing. Guardian Sustainable Business. Available online: https://www.theguardian.com/sustainable-business/2016/aug/20/greenwashing-environmentalismlies-companies (accessed on 19 August 2019).

79. Stiglitz, J.E.; Sen, A. The Measurement of Economic Performance and Social Progress Revisited Reflections and Overview. Doc. Trav. OFCE 2009, 33, 79.

80. Has GDP Become an Impediment to a Better Society? Financial Times. Available online: https://www.ft.com/ content/a9c7b6d8-08cc-11e7-ac5a-903b21361b43 (accessed on 4 August 2019).

81. Helliwell, J.F.; Layard, R.; Sachs, J.D. World Happiness Report; The United Nations Sustainable Development Solutions Network: New York, NY, USA, 2019.

82. WEAll Ideas: Little Summaries of Big Issues '7 Ideas for the G7'. Available online: https://wellbeingeconomy. org/wp-content/uploads/2019/08/Seven-Ideas-for-the-G7-2019.pdf (accessed on 4 September 2019). 
83. Open Democracy; Janoo, A. Our Economy: Seven Ideas for the G7. Available online: https://www. opendemocracy.net/en/oureconomy/seven-ideas-g7/ (accessed on 23 August 2019).

84. Morioka, S.N.; Bolis, I.; de Carvalho, M.M. From an ideal dream towards reality analysis: Proposing Sustainable Value Exchange Matrix (SVEM) from systematic literature review on sustainable business models and face validation. J. Clean. Prod. 2018, 178, 76-88. [CrossRef]

85. Morioka, S.N.; Bolis, I.; Evans, S.; Carvalho, M.M. Transforming sustainability challenges into competitive advantage: Multiple case studies kaleidoscope converging into sustainable business models. J. Clean. Prod. 2018, 167, 723-738. [CrossRef]

86. The Fourth Sector. Available online: https://www.fourthsector.org/supportive-ecosystem (accessed on 23 August 2019).

87. Neumeyer, X.; Santos, S.C. Sustainable business models, venture typologies, and entrepreneurial ecosystems: A social network perspective. J. Clean. Prod. 2018, 172, 4565-4579. [CrossRef]

88. WEAll Wellbeing Economy Alliance-Hub Guide. Available online: https://wellbeingeconomy.org/wpcontent/uploads/2019/05/WEAll-Hub-Guide.pdf (accessed on 23 August 2019).

(C) 2019 by the authors. Licensee MDPI, Basel, Switzerland. This article is an open access article distributed under the terms and conditions of the Creative Commons Attribution (CC BY) license (http://creativecommons.org/licenses/by/4.0/). 